\title{
Telecommunications monopoly eroded?
}

\section{Profiting from}

leased lines

\section{made seemly}

The most serious challenge yet to the British telecommunications monopoly came last week in a recipe for permitting outside access to the public network. A report by Professor Michael Beesley, Liberalization of the use of British Telecommunications Network, commissioned by the Department of Industry, argues that private persons and companies should in future be allowed to set up separate networks but also to market telecommunications services based on circuits rented from British Telecom.

In passing, the report provides a unique account of competition between telephone monopolies and those who use their circuits for marketing private services, notably in the United States. Thus MCI Inc., one of the survivors of the companies set up in the 1960s to provide data transmission services using lines leased from AT\&T (the telephone company), told Beesley that 91 per cent of its business now stems from voice and not digital transmission.

In principle, the Beesley report is intended to allow the British government to fill in some gaps in the Telecommunications Bill, still being discussed in the House of Commons. When the bill was published last October, the Department of Industry promised that provision would be made for private interests to lease lines from British Telecom, reselling the services thus made possible. In practice, opposition from British Telecom - and the sheer unfamiliarity of the Beesley proposals on the British scene - may postpone these developments.

Jargon for these services is VANS, or "value added network services". Beesley concludes that in the domestic British market there should be no restriction on the use made of British Telecom circuits by those who rent them. British Telecom, the report says, should be required to publish the costs of renting circuits of different kinds, and the charges made should be unrelated to the proposed uses. (British Telecom's proposal that it should charge royalties on VANS is rejected.) British Telecom itself should be free to compete in fields such as data transmission. Ultimately, Beesley argues, liberalization of the monopoly should be extended to the international market.

The crux of the report is Beesley's rejection of the British Telecom protest that liberalization would allow private users to "skim the cream" off its

telecommunications market. British Telecom itself has estimated that unrestricted use of its domestic circuits would lead to revenue losses of between $£ 30$ million and $£ 110$ million, and that one consequence would be slower development of the telecommunications network in Britain. Beesley doubts the arithmetic (which implies a faster growth of VANS services in Britain than in the United States), says that the public monopoly could safeguard its position by adjusting tariffs more accurately to costs and argues that the partitioning of the telecommunications market is not, in any case, a "zerosum game". The sale of VANS would increase the amount of business to be shared by British Telecom and those selling services based on leased circuits.

\section{Postgraduate medical schools in danger}

The University of London's postgraduate medical schools may be the first British academic institutions to bite the dust in the wake of government cutbacks in funds for higher education. A meeting between their representatives, Lord Annan (the vice-chancellor), the Secretary of State for Education and Science and the Health Minister, before Easter, did not secure more cash but did, apparently, convince the government of a problem that it had not known existed.

At risk are the 13 members of the British Postgraduate Medical Federation and two unassociated schools, the Royal Postgraduate Medical School and the London School of Hygiene and Tropical Medicine. Their problems began lası October, when government support for new overseas students was cut. The decision that such students should pay "economic" fees has since been exacerbated by reductions of central funds for universities.

The members of the British federation, with 44 per cent of their students coming from overseas, decided to charge the minimum recommended fee of $£ 5,000$ even though their average costs are considerably more. A further problem is that a fair proportion of their students are salaried staff whose fees are waived, for which the schools now receive no offsetting compensation. The result is a substantial deficit which this academic year the federation may just be able to balance with help from central funds.

The fear now is that matters will get worse. The intake of overseas students is expected to fall considerably next October. Already several governments, in particular those of Malaysia and Hong Kong which traditionally send many medically qualified students to study in Britain, have said that in future they will be sending students to cheaper universities in other countries. If the expected shortfall
As yet, Beesley finds, there is no clear pattern of how British private users would exploit the freedom to use British Telecom circuits. The most obvious starting point would be the provision of long-distance telephone services, perhaps of lesser quality, more cheaply than British Telecom. But several organizations with existing private networks - one of them the nationalized industry British Rail have ambitions to make more use of their existing telecommunications networks.

Although the Department of Industry, the department responsible for telecommunications, favours the principles underlying Beesley, the process of consultation is expected to take several months. Political and trade union opposition is likely to be fierce.

materializes, some of the federation's institutes may find themselves almost bankrupt by the end of the 1981-82 academic year.

That, according to Mr D. Innes Williams of the British federation, would have "disastrous consequences" for teaching and for London's health services. Most teaching and research would have to stop and the clinical staff would be absorbed into hospitals. One possibility, that could keep the institutes functioning although crippled, would be that the government should make up the costs after fees from overseas students have been deducted.

Another possibility, is that some of the smaller institutes could become departments of the major teaching hospitals. Discussions to incorporate the Institute of Dermatology into St Thomas's Hospital are already under way. The larger institutes, however, are hoping to manage on their own.

Although there are many similarities, each institute seems to have its own peculiar problems. The Institute of Basic Medical Sciences, for example, is considering merging with the Royal College of Surgeons, which would have to put up considerable funds to bail it out of its present difficulties.

The Institute of Cancer Research, which is affiliated to the university but receives no funds from it, is suffering not so much from the shortfall in overseas students as from a decision taken in 1977 by the Medical Research Council and the Cancer Research Campaign, which provide it with the bulk of its funds, to reduce their block grant. The institute is now in the position of having spent most of its reserves to make up the deficit and of having its block grant cut even further a year from now. Plans are already under way to persuade staff to retire early. Teaching may be cut in order to retain an adequate research base.

Judy Redfearn 